\title{
TECHNICAL COLLEGES AND INDUSTRY IN BRITAIN
}

\begin{abstract}
THE papers presented at the Conference on Technical Colleges and Industry arranged by the Education Committee of the Federation of British Industries at Ashorne Hill on May 5-7 covered a wide field. They attempted to formulate industry's ideas as to what it expects of the technical colleges in Britain, and, on the part of the technical colleges, to present the perspective in which the colleges work and their relations to the universities and the schools as well as to industry itself. Such discussions flowed naturally on to the broadening of the technical college and its place and function in training for management.
\end{abstract}

So far as the Conference leaves any dominant impression, it is one of the complexity of the whole problem of technical education in Britain, and the futility of any attempt to improve its standard or expand the provision for technical education without taking full account of the educational system of the country as a whole from university-level downwards, and in co-operation with industry. The inadequacy of such piecemeal tactics as the Ministry of Education has hitherto followed was clearly displayed, by implication rather than by explicit condemnation. There was no attempt to formulate a definite policy at the Conference; but essential features of any effective policy were indicated, though at the same time the need for flexibility and variety was equally stressed. It was certainly made clear that many sections of industry are already fully prepared to co-operate and that there should be a generous and prompt response to a clear and bold lead.

Sir Arthur Smout (Murex, Ltd., and Murex Welding Processes, Ltd.), in some outspoken comments on the present position, urged afresh the establishment of a Technical College Grants Committee on a par with the University Grants Committee, which would enable the administration and finance of at least the major technical colleges to be taken out of local and party politics. $\mathrm{He}$ insisted, too, that we cannot expect to have an educational system worthy of a great nation on the cheap, and while it was evident that industry as represented at the Conference is likely to support generously a policy of expansion for technical education, such support presupposes a policy and a recognition by the Government that technical education is a sound investment. Moreover, while it seemed to be generally admitted that only a relatively few technical colleges could be expanded into major institutions under such a policy, the importance of the contribution to be made to technical education by the rest was equally recognized. Dr. P. F. R. Venables (principal, Royal Technical College, Salford) suggested that the term 'higher technological education' should be restricted to postgraduate education; and this suggestion might well help not only to remove confusion but also to eliminate the difficulty, real or imaginary, which is sometimes caused by status. Dr. Willis Jackson, indeed, expressed the opinion that the weakness of Great Britain relative to the United States is at the level of technique and not at the professional level, and that post-war discussions here have concentrated too much on the professional grade rather than on the technician.
Much that was said at the Conference served to clarify these interrelationships. Sir Arthur Smout, for example, pointed out that we must get away from the idea that all higher education must be of the university type, and he visualized the technical colleges as the appropriate means for training for industry young men who are ill-suited and illequipped for university life. Further, he believes that a main purpose of the 'sandwich system' is to encourage a good type of recruit to join smaller firms direct from a grammar or secondary school and obtain the appropriate technical training in a technical college while based on the works. Apart from thus integrating practical training in the factory with technological studies in the college, Sir Arthur sees great advantages in bringing the smaller firms into relationship with technical colleges in this way.

The importance of maintaining a variety of channels for technological training was emphasized by other speakers. Dr. Venables pointed out that the fulcrum of the definition of technology is in the scientific study, while with a craft it is in the exercise of a skill or technique. Fundamentally, a technology requires the student to undergo an exacting scientific discipline which confers mastery of the theoretical concepts required for widely differing ends. In his view the difference between technological education in the universities and in the technical colleges is simply one of the timing or phasing of the two main elements - the science and the art of the technology. In the universities, the phasing is preponderantly scientific, with the art phase introduced mainly as a pre-undergraduate year, as brief intermittent phases of vocational experience in industry, and a thorough postgraduate phase; but for most technical college students the phases are more interpenetrating or even concurrent or alternate as in 'sandwich courses'. While he believes there is an ample reserve of ability in Britain for training in technical colleges, it is on condition that such expansion of the technical colleges does not contemplate the raising of more than the minority of such colleges to provide largely technological, as distinct from technician or craft, education. We should preserve flexibility and also encourage transfer between courses and occupations, so that the best ability when found can be moved forward and upward.

Dr. Venables suggested that the main elements in our policy should be the development of 'sandwich courses' on a recognized national basis, a national standard of intake and a national length of courses. This would remove much of the present confusion, and though he believes it is also desirable that more research should be carried out in the technical colleges, that depends on the recruitment of the appropriate staff and the establishment of conditions of service which will attract competent men. Dr. Willis Jackson (Metropolitan-Vickers Electrical Co., Ltd.) supported Dr. Venables in his general view as to the relative functions of the universities and the technical colleges; the latter, he suggested, should provide courses which are more technical and more related to industrial practice. Some university courses are already technical enough, and he would like to see the universities rather ensure a sounder foundation 
in pure science. Moreover, in view of the increasing interrelation of different branches of technology and their increasing mutual dependence on pure science, he believes they should be drawn together at a comparable level and in intimate association with pure science departments of high standing.

Dr. Jackson did not minimize the difficulty of any such attempt; but he also urged that the technical colleges rather than the universities should encourage the development of short-term specialist courses, whether full-time or evening, and the universities should concern themselves only with the scientific and analytical foundations of prospective technological development-with what industrial practice should be five or more years ahead rather than with what it is to-day. The technical colleges, moreover, can only make their full contribution in the teaching of current industrial practice if industry is willing to cooperate to the extent of making available the services of the appropriate senior members of its staff.

In opening the discussion" on the broadening of technical education, Sir Reginald Vernon Smith (Bristol Aeroplane Co., Ltd.) pointed out that the responsibility once again rests with the schools and industry as well as with the technical colleges. So far as industry is concerned, the standard of selection adopted by industry for its recruits is an important factor, as is the pattern of training afterwards given. Technical education, moreover, is a continuing process and much can be done by the intelligent and liberal use of postgraduate courses, residential courses, interchange schemes, overseas travel fellowships and the like. On the part of the technical colleges, ho suggested, like Dr. Venables, that emphasis should be placed more on the fundamentals or intellectual discipline of a technology than on the applications, and that technical subjects should be presented against a stimulating background of historical development and in relation to allied subjects. The latter suggestion found confirmation in Prof. Rex Knight's observations on the probable reaction of technical collego students to the widening of their programme of studies. Prof. Knight (professor of psychology, University of Aberdeen) believes that any new subjects must be linked to subjects of which the vocational significance is clear; they must be seen by the student to be an integral part of the preparation for the job he is to do in industry. 'They must also, he thought, form part of the target the student has to hit, though not necessarily as subjects of examination. Prof. Knight also remarked that much of the widening of curriculum would have to be done in industry, and while he believes that in the technical colleges, even more than in the universities, there is great need for grading students according to their ability and educational achievements, to facilitate both the prosecution of their individual studies and the removal of specific defects in their educational equipment, he stressed finally that all such further education is dopendent on effective co-operation between all concerned. He also endorsed Dr. Venables's remark as to the importance of social facilities, and the suggestion that the Federation of British Industries might press for greater proportionate facilities for technical college students.

Mr. H. A. Warren (principal, South-East London Technical College), who followed Sir Reginald Verdon Smith, from the point of view of the technical colleges went rather deeper into the implications of the broadening of technical education. It should be remembered, he pointed out, that this age is extremely preoccupied with technics, and we have above all to present technies or technology as a means to an end in terms of human values, not as an end in itself. If we fail to put power into the hands of the coming generation with a sense of purpose and of responsibility, we are in danger of being overwhelmed by an environment of our own making. Technical education, moreover, is wholly secular, and more regard should be paid to those fundamentals of the human spirit which limit and constrain technical education. With much of what Prof. Knight said he agreed; but he emphasized that the decisive factor is the outlook and capacity of the teacher, and here, he said, the Federation of British Industries can be of great assistance. The Federation can also make it widely known that industry desires and values this broadening of technical education.

Dealing specifically with management studies in the technical colleges, Mr. Bertram White (formerly technical director of the Federation of British Industries) said that the technical colleges have here a valuable but limited contribution to make. He too stressed the importance of the quality of the teaching and suggested that the Urwick Committee was over-optimistic in its estimate of the potential supply of men and women with appropriate experience willing to devote part of their time to the teaching of management. He believes that lectures on management are often delivered by teachers with no practical industrial experience; indeed, generally the business community lacks the faculty of coherent and articulated expression of its ideas. While much closer association with the professional associations is required, any further development of management studies should proceed by way of agreement. Much closer association between the technical colleges and local industry is required, particularly in teaching the various techniques through which management achieves its purposes. Besides this, technical collegos in their management studies should endeavour to teach background subjects : those aspects which are usually termed 'general management' subjects are best learned on the job under good supervision. Industry must train its own managers; the role of the technical colleges is supplementary. He advocated the abandonment of courses that are ineffective and cannot be improved and also, for the next decade, disregard of certificates and diplomas in management studies. The Federation of British Industries and the British Institute of Management should confer with the associations of technical institutes to ascertain those areas of the country in which more co-operation between industry and the technical colleges and greater awareness of the value of management training are required.

Mr. J. Wilson (principal, Birmingham College of Technology), who followed, agreed that most of the difficulties in education for management arise from over-enthusiasm and pressure for development started up by the Urwick Report. 'There has been some lack of consultation with industry ; but the staffing position is the critical factor and limits the rate of progress. $\mathrm{He}$ also agreed that it is desirable to concentrate highly qualified staff in a few centres providing facilities for all levels of interest in industrial adminis tration. The urgent need in the training of men for management is to bring into partnership all those bodies already concerned with it separately, from universities to trade unions, from technical colleges to professional associations, and from public to private enterprises. 